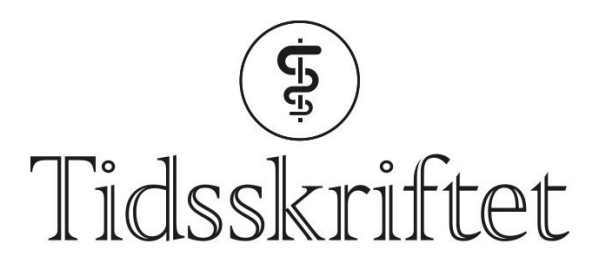

DEN NORSKE LEGEFORENING

\title{
P-pillens problematiske pakningsprospekt
}

TIDLIGERE I TIDSSKRIFTET

\section{JULIE DIDRIKSEN}

Tidsskriftet

P-pillen kom til Norge i 1967. I Tidsskriftet nr. 12/1972 sto en liten sak om at pakningsvedlegget ikke stemte overens med det Helsedirektoratet mente (Tidsskr Nor Lægeforen 1972; 92: 881).

\section{P-piller. Revurdering av advarselstekst}

Det er mange kvinner som er blitt skremt av den advarselstekst som har vært vedlagt P-pillepakninger og har gjennomlevet 9 måneders unødig engstelse - eller har forsøkt å få abort av frykt for at barnet skulle bli misdannet.

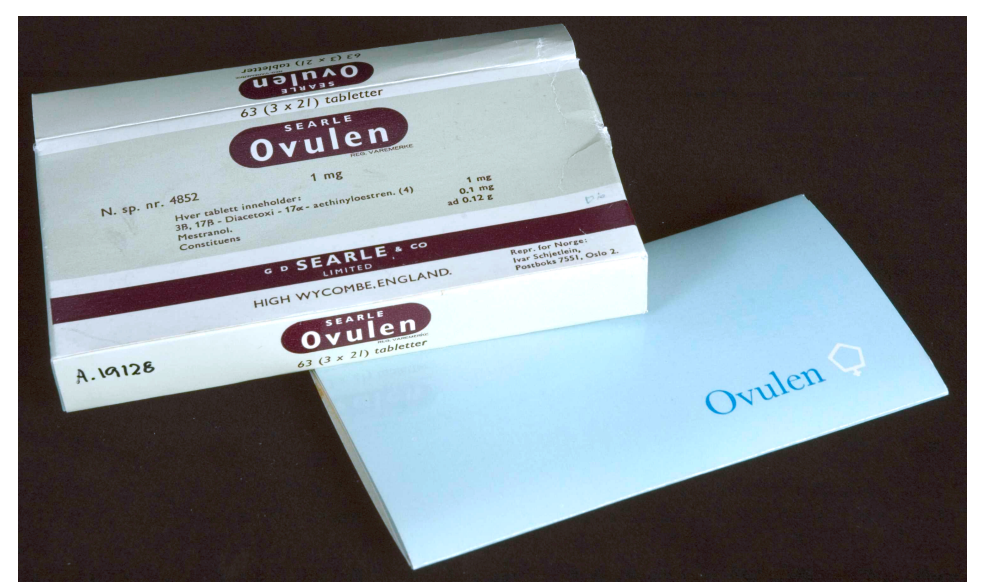

Pakning til p-piller fra tidlig i 1970-årene. Foto: Anne-Lise Reinsfelt / Norsk Farmasihistorisk museum, lisensiert under CC BY-SA.

Saken er tatt opp med Institutt for Farmakoterapi av en legefrue som har lest Helsedirektoratets brosjyrer om P-piller og funnet at det ikke var overensstemmelse mellom disse og pakningsprospektene.

I det pakningsprospekt som medfulgte hennes P-piller, var det angitt at preparatet kan skade fosteret hvis det blir brukt under svangerskap, og at veksten kan stanses for tidlig hos unge piker (under 18 år) hvor lengdeveksten ikke er avsluttet.

I Helsedirektoratets brosjyre står det derimot: «Det er ikke forbundet med noen risiko for fosteret om man ved en misforståelse skulle komme til å ta «P-pillen» i en periode under svangerskapet. «P-pillen» fører heller ikke til abort. Et svangerskap vil utvikle seg som ellers 
hvis man bruker «P-pillen». De små doser kjønnshormoner som tilføres gjennom pillene, er helt ubetydelige i forhold til de mengder av samme typer hormoner som kroppen selv produserer under svangerskapet. En annen sak er at man selvsagt må slutte å ta «P-pillen» under svangerskap så snart misforståelsen oppdages.»

Om bruk av P-piller hos tenåringer står det i brosjyren: «Piker i tenårene vil ikke sjelden ha behov for sikker prevensjon, og ofte er «P-pillen» den eneste formen de vil akseptere. Legene er tilbakeholdne med å forskrive «P-piller» til de helt unge, fordi menstruasjonen og samspillet mellom kjønnshormonene ikke alltid er helt veletablert. Dette kan føre til uregelmessigheter når de holder opp å bruke «P-pillen». Ved uttalt behov, og der legen finner at forholdene ellers er normale, kan «P-pillen» også forskrives til unge kvinner selv om de ikke har fylt 20\%.

Som ny tekst på pakningsprospektet har Helsedirektoratet nå påbudt: «Preparatet skal ikke benyttes av kvinner som ikke har etablert regelmessig menstruasjon. Hvis man merker tegn på svangerskap, skal man straks slutte å ta preparatet».

Produsentene har fått pålegg om å foreta disse forandringene innen 1. mai 1972.

A.R.

Publisert: 4. februar 2019. Tidsskr Nor Legeforen. DOI: 10.4045/tidsskr.18.o926

(C) Tidsskrift for Den norske legeforening 2020. Lastet ned fra tidsskriftet.no 